\title{
The Relationship between Customer Satisfaction and Loyalty: Evidence on Online Transportation Services in Indonesia
}

\author{
Ady Widjaja ${ }^{1}$, Widji Astuti ${ }^{2}$ and Abdul Manan ${ }^{3}$ \\ ${ }^{1}$ Doctoral Program in Economic Science \\ ${ }^{2,3}$ Faculty Economics and Business \\ University of Merdeka Malang \\ Indonesia
}

\begin{abstract}
Need a vehicle that can deliver the intended to place someone in a fast and safe is very important and is increasing lately. The use of the two-wheeled vehicle is an appropriate alternative to the congestion in the Centre of the drive. PT. GOJEK is a company which provides services for delivering customer-driven applications. Customers who want to use the GOJEK service should first download and install the application to a smartphone. This application makes it easy for someone who needs transportation to travel, the application will then be connected with a taxi driver and a taxi driver online. Then a taxi online will come to the location of the caller. The caller the taxi online already gives the destination location in the applications and will calculate the cost and the caller can consider those costs. Unlike the Ojek base, which we should approach a taxi and ask for the price of the targeted destination. This research will examine whether the satisfaction of customers will affect customer loyalty at PT. GOJEK Indonesia.
\end{abstract}

Key Words: Customer Satisfaction, Online Application, Loyalty, Transportation.

\section{INTRODUCTION}

The utilization of E-Commerce in the business world is increasingly rapidly. Electronic commerce (E-Commerce) is part of the e-lifestyle that allows buy and sell transactions conducted online from any place. E-Commerce is a business transaction that occurs in electronic networks such as the internet. Anyone who has the internet network can participate in the activities of ECommerce.

The industrial revolution made taxi transportation PT. GO-JEK Indonesia as a pioneer and leader company engaged in ecommerce based business. E-commerce offered by GO-JEK in the form of services contained on the features of the application. The presence of e-commerce on GO-JEK is expected to help meet the community's needs and facilitate the transportation of Indonesia in carrying out daily activities. Online taxi or two-wheeled transport application online, is a two-wheeled transportation service which first introduced and is being a famous. Online taxi service much needed community, since it provides easy, cheap, safe, and fast. Especially for transportation on the streets are congested, in order not to take more time on the trip, then an online solution. Traditional taxi transportation with transport-taxi application online have fundamental differences. Online taxi transport technology utilizing smartphone so that everyone in Jakarta can download the application online for visitors. This application makes it easy to someone who needs help with transportation, stay using the application, it will be connected with a taxi driver online, online taxi and the driver will go to customers in the specified location to deliver customer or order to destination. online taxi caller or customers who need an online inform the destination location on the taxi application online and the application will calculate the cost to be paid, then the caller i.e. customers who will be using their online can be consider these costs

\section{LITERATURE REVIEW}

\subsection{Satisfaction}

Customer satisfaction is the evaluation after the purchase of the selected alternative is at least equal or exceed customer expectations, while dissatisfaction arose when the result (result) does not meet expectations (Engel,et.al, 1995:187). Different views are expressed Kotler (2006:177) define satisfaction is a feeling one's pleasure or disappointment resulting from comparing perceived product. Kotler and Keller $(2012,10)$ holds that Satisfaction reflects the perceived product performance assessment in 
conjunction with hope. If performance falls short of expectations, customers are disappointed. If it fit the expectations, the customer is satisfied. If it exceeds their expectations then the customer happy and definitely satisfied.

The process of formation of consumer satisfaction starts from past experience, information from relatives or relation and information submitted by the companies as presented in Figure 1 below :

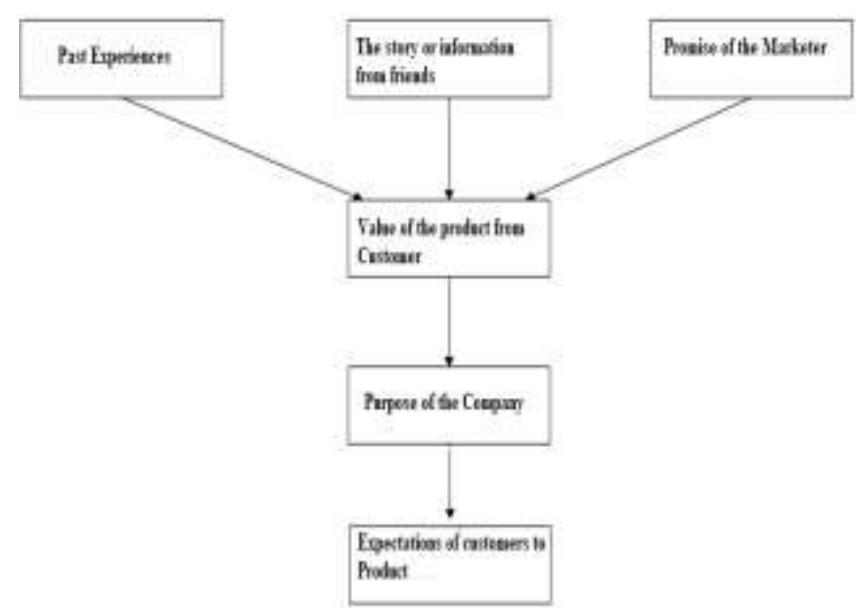

Figure 1. The process of formation of Consumer/Customer Satisfaction

\subsection{Customer loyalty}

Customer loyalty is the customer behavior against the Organization, as well as view Zeithaml, Berry \& Parasuraman (1996), customer loyalty is a prediction about the future intentions of customers to do business with the company. While according to Oliver (1999), customer loyalty is the overall behavior of customers about products, services or any other aspect of the organizations that involve customers. Thus customer loyalty is the description of the attitudes and behavior of customers. Hurriyati (2005:130) reveal the definition of customer loyalty: Loyalty is the commitment of customers endure in depth to subscribe or make a purchase again reset the selected product or service on a consistent basis in the future, although the influence of the situation and the marketing efforts have the potential to cause behavior change.

Consumer loyalty can be measured in several ways, among others (Schiffman and Lazarkanuk, 2001, 259):

a. Consumers considered loyal if consumers had been doing at least the three times repeated purchases at the same company.

b. Loyalty can be measured by observing the proportion of use of the service by the company, in which a family is always faithful to utilize services provided company.

c. Loyalty can be measured from the attitude of consumers to the company.

d. Loyalty can be measured from the level of involvement.

Customer loyalty is important in ensuring the existence of the product, the brand and the company in the long run, however, build customer loyalty is not an easy thing. The performance of the product and the company became the central point woke up customer loyalty

According to Aaker (2008:26) There are four values to be gained loyal customers:

a. Reduce marketing costs. A customer base that has brand loyalty may reduce marketing costs because it will be cheaper than getting brand retaining new customers.

b. Boost trade. The trading result in increased brand loyalty and also dominate the buying decision.

c. The lure new customers. A satisfied customer base and like certain brands can result in conviction for the prospect, in particular purchasing it rather contains risks.

d. Give time to respond to those threats competitors. Loyalty gives breathing space at such time a company to respond to the movements of competitive rivals.

\subsection{Research Problem}

Problems that occur at PT. GOJEK Indonesia is a study of customer satisfaction that does not affect customer loyalty. So if customer loyalty decreases it cannot be known whether these factors originate from customer satisfaction. 
International Journal of Advances in Scientific Research and Engineering (ijasre), Vol 5 (4), April-2019

\section{RESEARCH METHODS}

The instruments used in this study are a questionnaire with a few items statement. Instruments questionnaire used in the study because the data contained in the questionnaire is a pure data from respondents research (primary data). On this questionnaire data using 200 Respondents. In this questionnaire the customer responded by giving it a cross mark (X) on a choice answers provided. Data were analyzed using Importance Performance Analysis (IPA) and Partial Least Square (PLS)

\subsection{Partial Least Square (PLS)}

According to Imam Ghozali (2006:1) the method of Partial Least Square (PLS) is explained as follows: Model-based variance structure equation. PLS latent variables able to describe (unmeasurable) and measured using the indicators (the manifest variables). This model was developed as an alternative for situations where basic theory on designing a model of weak or indicators that are available do not meet model measurements of reflexive

\subsection{Importance Performance Analysis (IPA)}

Analysis Quadrant or Importance Performance Analysis (IPA) is a descriptive analysis technique introduced by John a. Martilla and John c. James 1977 year. Importance Performance Analysis is a technique of analysis used to identify important performance factors what must be demonstrated by an organization to meet the satisfaction of the users of their services (consumers). The results of the research quadrant Martilla and James exemplified as follows:

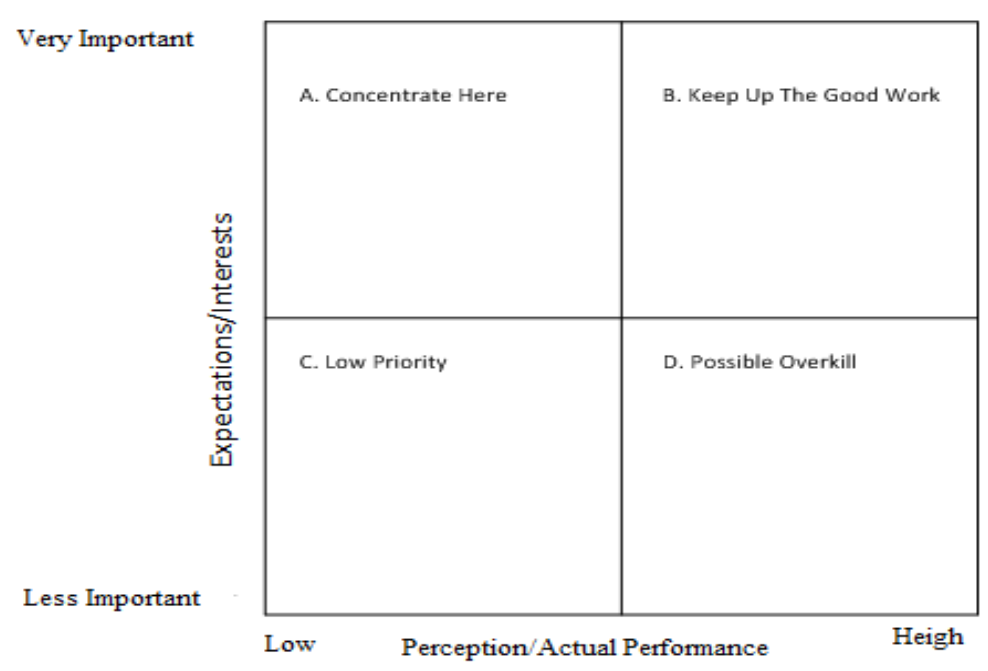

Figure 2. Importance Perfomance Analysis (IPA)

A. Concentrate Here.

Factors that are located in this quadrant is regarded as an important factor and or expected by the consumer but the condition or perception and actual performance that exists at this moment has not been satisfactory so that the management is obliged to allocate adequate resources to improve the performance of a variety of factors. Factors that lie in this quadrant is a priority for improved.

B. Keep up with the good work.

Factors that lie in this quadrant are considered important and expected as a supporting factor for customer satisfaction so that the management shall be obliged to ensure that the performance of the institutions managed can continue to maintain the achievements has been achieved.

C. Low Priority.

Factors that lie in this quadrant have a perception or actual performance levels are low at once is not considered too important or too expected by consumers so that management need not prioritize or too provide attention to those factors.

D. Possibly Overkill.

Factors that lie in this quadrant is not considered too important and Too or not Expected so management needs to allocate resources that are associated with those factors to other factors that have the higher handling priority still needs improvement, such as in quadrant B 
International Journal of Advances in Scientific Research and Engineering (ijasre), Vol 5 (4), April-2019

\section{RESULT AND DISCUSSION}

\subsection{Results Analysis Description}

a. Results Analysis Description Customer Satisfaction

\begin{tabular}{|c|c|c|c|c|c|c|}
\hline \multirow{3}{*}{ No Statement } & \multicolumn{5}{|c|}{ Seale } & \multirow{3}{*}{ Mean } \\
\hline & 1 & 2 & 3 & 4 & 5 & \\
\hline & $\begin{array}{l}\text { Very } \\
\text { Dikagree }\end{array}$ & Dinagre & Hesitatien & Agree & $\begin{array}{l}\text { Very: } \\
\text { Agree }\end{array}$ & \\
\hline $\begin{array}{l}\text { Ojek online altemative } \\
\text { tumuportation con restion }\end{array}$ & 3 & 4 & 21 & 110 & 62 & 412. \\
\hline $\begin{array}{l}\text { Ojdk online serving esconted } \\
\text { safely }\end{array}$ & 7 & 8 & 33 & 88 & 64 & 3.97. \\
\hline $\begin{array}{l}\text { Ojek online serving } \\
\text { castomets for } 24 \text { houn }\end{array}$ & 23 & 6 & 49 & 86 & 36 & 3.53 \\
\hline $\begin{array}{l}\text { I didn't wal foe lase tiate in } \\
\text { need of trasspertation gjok } \\
\text { onlie }\end{array}$ & 3 & 16 & 64 & 87 & 30 & 3.63 \\
\hline $\begin{array}{l}\text { linvite a friend to use the } \\
\text { ride giek. }\end{array}$ & 15 & 19 & $2 ?$ & 98 & 41 & 3.66 \\
\hline $\begin{array}{l}\text { I sugset my brother to use } \\
\text { pide rojak }\end{array}$ & $?$ & 17 & 30 & 115 & 31 & 3.73 \\
\hline Perroatage \& Amege (C) & 483 & 5.59 & 15.67 & 45.67 & 22.00 & 3.77 \\
\hline
\end{tabular}

From the results of the Analysis Description Variable customer satisfaction can be seen that percentage and an average of $48.67 \%$ strongly agree that means that customers are very satisfied by the service against PT Gojek Indonesia. Of the value of the mean unobtainable values of percentage and an average of 3.77 meaning if the value of the mean above the variable then 3.77 affordable and if under less well worth 3.77 .

b. Results Analysis Description Customer Loyalty

\begin{tabular}{|c|c|c|c|c|c|c|}
\hline \multirow{3}{*}{ No Staicmerut } & \multicolumn{5}{|c|}{ Srale } & \multirow{3}{*}{ Mean } \\
\hline & \multirow{2}{*}{$\frac{1}{\text { Yery }}$} & \multirow{2}{*}{$\frac{2}{\text { Disagres }}$} & \multirow{2}{*}{\begin{tabular}{|c|}
3 \\
Hinsitation
\end{tabular}} & \multirow{2}{*}{4} & \multirow{2}{*}{ 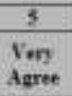 } & \\
\hline & & & & & & \\
\hline $\begin{array}{l}\text { When I use public transpont I } \\
\text { use oje online }\end{array}$ & 3 & 14 & 40 & 113 & 30 & 3.77 \\
\hline $\begin{array}{l}\text { Thelieve an ojek caline une } \\
\text { public transportation I need }\end{array}$ & 4 & 13 & 34 & 112 & 37 & 3.83 \\
\hline $\begin{array}{l}\text { I m proud to use } \\
\text { tramportation gjek online }\end{array}$ & $?$ & 22 & 68 & 73 & 30 & 3.49 \\
\hline $\begin{array}{l}\text { Tbelieve odek coline reaty to } \\
\text { assist travel amid the } \\
\text { congestion. }\end{array}$ & B & 37 & 67 & $\pi$ & 17 & 3.26 \\
\hline $\begin{array}{l}\text { Ojek ouline is fast safe } \\
\text { transportation solution }\end{array}$ & 9 & 10 & 42 & 108 & 31 & 3.71 \\
\hline $\begin{array}{l}\text { The driver ofek online honed } \\
\text { in accegeing the puymeat } \\
\text { invice }\end{array}$ & 7 & 15 & 30 & 107 & 41 & 3.80 \\
\hline Percentuge $\&$ Arerage (S) & 3.17 & 9.25 & 23.42 & 45.67 & 15.50 & 3.64 \\
\hline
\end{tabular}

From The Results Of The Analysis Of The Description Of Variable Customer Loyalty. It can be seen that percentage and an average of $48.67 \%$ strongly agree that means that customer loyalty PT. Gojek Indonesia can be maintained properly. Of the value of the mean unobtainable values of percentage and an average of 3.64 meaning if the value of the mean of that variable is then 3.64 above good value and if it is below 3.64 worth less well.

\subsection{Test Validity}

The validity of a test intended to find out the extent to which measuring instruments used can measure what will be measured. Test validity in this research intended to find out whether the questionnaire prepared have been able to measure the variables wanted measured. The validity of a test is done by calculating the correlation of each of questions (items) with a score total.

\section{a. Test validity of the variable customer satisfaction}

Based on a test of the validity of customer satisfaction, Variable on indicator driver of gojek meet the completeness of the equipment for passengers (helmets, masks, raincoats) loading factor value of 0.500 and 0.728 criteria as well as the description is valid. On indicator driver of gojek has a way of helping the complete problem in the passenger loading factor value of 0.500 and 0.686 criteria as well as the description is valid. On the indicator in the case of passengers asking for something (reduce speed, possession of the route, etc.), the driver gojek can decide to meet the loading factor value of 0.500 and $0.581 \mathrm{criteria}$ as well as the description is valid. On indicator Gojek alternative transportation fast loading factor value of 0.500 and 0.644 and criteria as well as a description of valid.

From the table of satisfaction in table appendix of 0.538 AVE has a value which means valid. From the results of testing the validity of variables of satisfaction can be seen that the gojek meet the Drivers indicators completeness of the equipment for passengers (helmet, raincoat, mask) have a very important influence. Customers feel the completeness of a complete drive so that the customers are satisfied and safe when driving. 


\section{b. Test Validity of the Variable Customer Loyalty}

Based on a test of the validity of the variable customer loyalty on the indicator Gojek drove safely loading value of 0.500 and 0.730 criteria as well as the description is valid. On indicator I don't wait long time require transport gojek has a value of loading of 0.737 and 0.500 criteria as well as the description is valid. On indicator I invite a friend to use the ride gojek has a value of 0.593 and loading criteria valid description 0.500. On indicator I encourage Brothers to use the ride gojek has a value of loading of 0.665 and criteria as well as a description of valid 0.500 . In General, the purposes of the transportation indicator I use gojek has a value of loading 0.615 and 0.500 so valid information.

Loyalty has value from a table of 0.550 AVE which means valid. From the results of Testing the validity of Variables may be advised that Loyalty indicators I don't wait long time require transport gojek has a very important influence in customer loyalty. Customers feel no need to wait for a long time when ordering Go-Jek, so for the purposes of the very urgent need not wait for a long time. So that customer loyalty is getting awake.

\subsection{Test Reliability}

Test reliability is a measure regarding the internal consistence of indicators a construct shows the degree to which the indicator it indicates a constructs or latent factors. The value of reliability calculated with a coefficient Alpha Cronbachs Alpha coefficient values where Cranach's $>0.6$ is reliable (Sudarmanto, 2013:81).

Based on a test of Reliability, all research variables have the value of Cronbach Alpha > 0.6 so that all research is variable reliability

\subsection{Test Hypothesis}

This hypothesis test is done to find out the relation between the respective variables. Variable of satisfaction manifested Loyalty towards significantly influential if the value of the T-Test statistical Hypotheses Of $1.96>$ can note that the results of the Tstatistic is worth 6.795. Customer satisfaction is very effect on customer loyalty.

\subsection{Quadrant IPA}

\section{a. Customer Satisfaction}

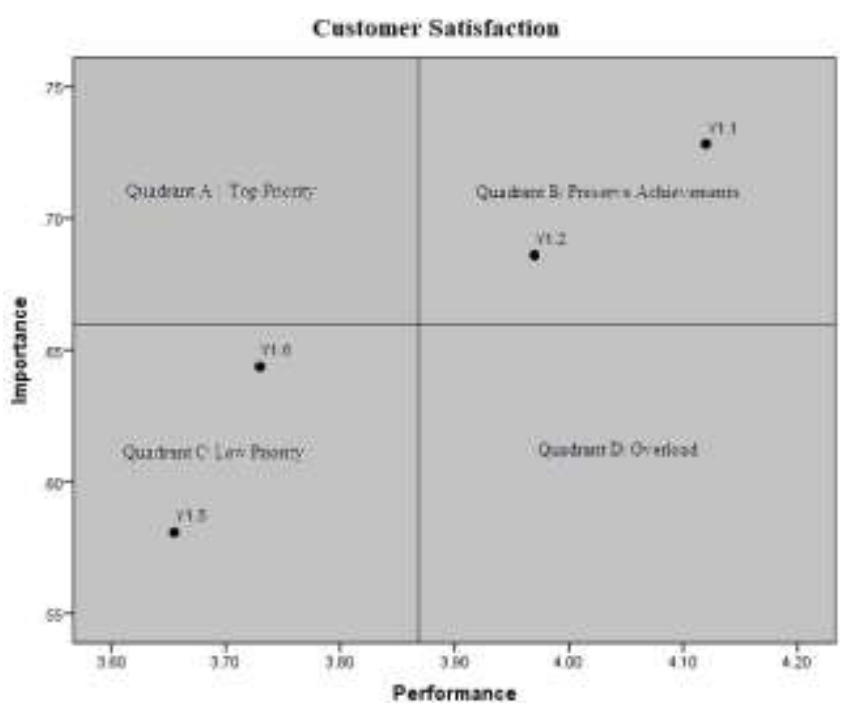

Figure 3. Quadrant IPA Customer Satisfaction

Customer satisfaction indicator variable Y1.1 and Y1.2 into Quadrant B namely Preserve Achievements (Keep Up The Good Work) so that the indicator Y1.2 and Y1.1 is an important and influential indicator to customers and the company is obliged to maintaining the performance accomplishments. On indicator Y1.5 and Y1.6 indicators into the Quadrant C (Low Priority) so that the indicator Y1.5 and Y1.6 indicators is not too important or not too influential by the customer so that companies do not need to prioritize or to give more attention to the indicators. 


\section{b. Customer Loyalty}

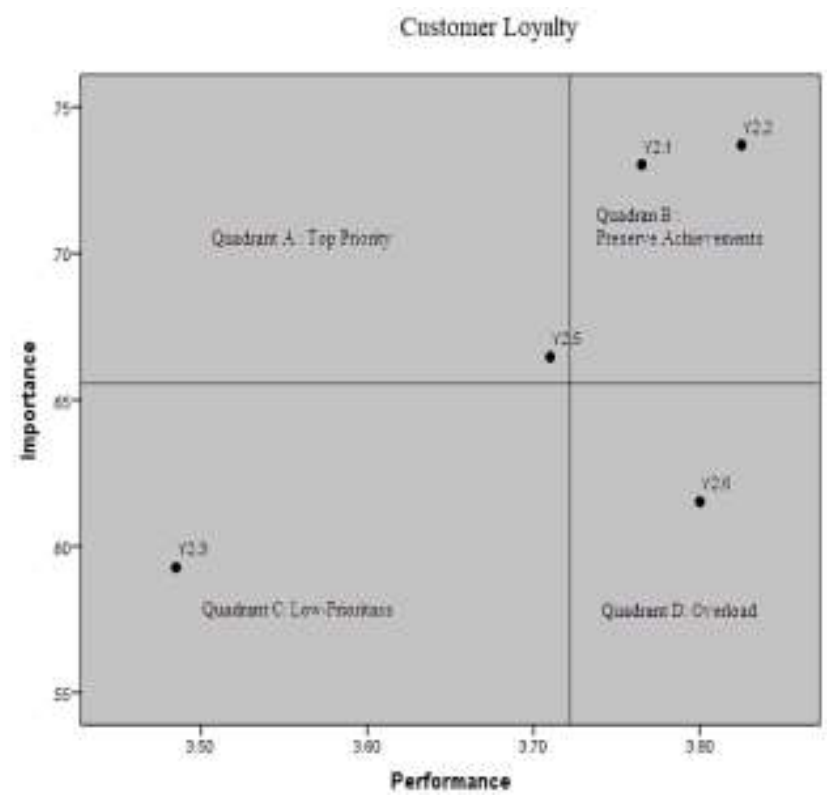

Figure 4. Quadrant IPA customer loyalty

Variable customer loyalty, indicator Y2.5 in A Quadrant that is a top priority (Concentrate Here) so that the indicator Y2.5 which is considered important or influential to customers, so companies need to concentrate for the party allocating its resources in order to improve performance that goes on the indicator Y2.5. On indicator indicator Y2.1 and Y2.2 into Quadrant B namely Preserve Achievements (Keep Up The Good Work) so that the indicators Y2.1 and Y2.2 is an indicator of the important and influential to customers and the company is obliged to maintaining the performance accomplishments. On the indicator Y2.3 in Quadrant $\mathrm{C}$ (Low Priority) so that the indicator Y2.3 is not too important or not too influential by the customer so that companies do not need to prioritize or to give more attention to These indicators on the indicators Y2.6 into Quadrant D (Possibly Overkill) so that the indicator Y2.6 doesn't really matter and not too influential to customers. so the company better allocate resources related to these indicators to the indicators of other more have higher priority level

\section{CONCLUSION}

Based on the results of research and discussion, the influence of satisfaction against customer loyalty can be taken the following conclusions:

a. Based on the results of the t-test statistics retrieved value 6.75 which means the satisfaction of a customer of the service Gojek greatly affect customer loyalty.

b. Distribution of the answer a questionnaire towards customer satisfaction of users Go-ride the retrieved value $48.67 \%$ said agree, 22.00 strongly agree, 18.67 doubt, disagree 5.83 and 4.83 strongly disagree. So it can be deduced gojek customers are satisfied of the service Go-ride

c. Distribution of questionnaires And Loyalty against 48.67 value obtained agrees, 23.42 hesitated, 15.50 strongly disagree, 9.23\% disagree, and $3.17 \%$ strongly disagree so Loyal customers can be summed up and want to use Go-ride.

d. Reliability test results obtained From the value of the Cronbachs Alpha customer satisfaction 0.77 and customer loyalty 0.79 . Means the variable riliabel or consistent.

e. From Quadrant IPA about customers satisfaction can note that indicator Y1.1 and Y1.2 is an indicator that affect customer satisfaction, so that companies must maintain these indicators

f. From Quadrant IPA about customer loyalty can note that indicator Y2.5 is an indicator that influence customer loyalty, so companies have to maintain such indicators.

\section{RECOMMENDATIONS}

Research conducted by researchers about the influence of customer satisfaction toward customer loyalty is earned loyalty that customers will result if the satisfaction is met. Future research can be developed with the additions of variables that can affect customer loyalty other than customer satisfaction. 


\section{REFERENCES}

1. Aaker, D. A. 2008. Managing Brand Equity: Capitalizing on the value of a brand name. New York: Free Press

2. Engel, James F., Roger D. Blackwell, and Paul W. Miniard, 1995. Consumer Behavior. 8th Edition. Fort Worth, Dryden Press

3. Ghozali, Imam, 2006, Structural Equation Modeling Alternative Methods with Partial Least Square, Diponegoro University Publishing Agency, Semarang

4. Hurriyati, R. 2005. Mix of Marketing and Consumer Loyalty. Alfabeta, Bandung

5. Kotler, Philip and Keller, Kevin Lane, 2009, Marketing Management vol. 2, 13th Edition, Jakarta: Erlangga Publisher

6. Kotler, Philip, 2012, Marketing Management, 14th Edition, Prentice Hall, New Jersey.2006, Marketing, 6th ed., Frencks Forest, NSN: Pearson Education Australia.

7. Oliver, Richard L, 1999, "Whence consumer loyalty? Journal of Marketing, Vol.63, p 33-44.

8. Schiffman and Lazarkanuk, 2001, Customer Behavior, Prentice Hall, Jakarta

9. Varmaat, Shelly Cashman, 2007, Discovering Computers: Exploring the Fundamental Computer World. Issue 3, Salemba Infotek, Jakarta

10. Zeithaml, Berry and Parasuraman, 1996, "The Behavioral Consequences of Service Quality," Journal of Marketing, April, p.31-46.ryden Press 
International Journal of Advances in Scientific Research and Engineering (ijasre), Vol 5 (4), April-2019

TABLE APENDIX

Research Instrument Customer Satisfaction

\begin{tabular}{|c|c|c|c|c|c|c|c|}
\hline \multirow[t]{2}{*}{ Variable } & \multirow[t]{2}{*}{ Indicator } & \multirow[t]{2}{*}{ Statement Items } & \multicolumn{5}{|c|}{ Score } \\
\hline & & & 1 & 2 & 3 & 4 & 5 \\
\hline \multirow{3}{*}{ Satisfaction } & $\begin{array}{l}\text { 1. Satisfy Customer } \\
\text { Expectation }\end{array}$ & $\begin{array}{l}\text { a. Ojek online alternatve transportation congestion } \\
\text { b. Ojek online escorted safely }\end{array}$ & & & & & \\
\hline & 2. Easy to obtaining & $\begin{array}{l}\text { a. Ojek online serving customers for } 24 \text { hours. } \\
\text { b.I didn't wait for long time in need of transportation } \\
\text { ojek online }\end{array}$ & & & & & \\
\hline & $\begin{array}{l}\text { 3. Willingness to } \\
\text { recommend }\end{array}$ & $\begin{array}{l}\text { a. I invite a friend to use the ride gojek } \\
\text { b. I Suggest my brother to use ride-Gojek }\end{array}$ & & & & & \\
\hline
\end{tabular}

Research Instrument Variable Loyalty

\begin{tabular}{|c|c|c|c|c|c|c|c|}
\hline \multirow[t]{2}{*}{ Variable } & \multirow[t]{2}{*}{ Indicator } & \multirow[t]{2}{*}{ Statement Items } & \multicolumn{5}{|c|}{ Score } \\
\hline & & & 1 & 2 & 3 & 4 & 5 \\
\hline \multirow{3}{*}{ Loyalty } & $\begin{array}{l}\text { 1. Repeat } \\
\text { Purchase }\end{array}$ & $\begin{array}{l}\text { a. When I use public transport, I use Ojek online } \\
\text { b. I believe an ojek online one public transportation I need }\end{array}$ & & & & & \\
\hline & 2. Retention & $\begin{array}{l}\text { a. I am Proud to use transportation ojek online } \\
\text { b. I believe ojek online ready to assist travel amid the congestion }\end{array}$ & & & & & \\
\hline & 3. Referalls & $\begin{array}{l}\text { a. Ojek online is fast safe transportation solutions } \\
\text { b. the driver ojek online honest in accepting the payment service }\end{array}$ & & & & & \\
\hline
\end{tabular}

Test Validity Variable Customer Satisfaction

\begin{tabular}{|c|c|c|c|c|}
\hline Indicator & $\begin{array}{l}\text { Loading } \\
\text { Factor }\end{array}$ & AVE & Criteria & Description \\
\hline \multicolumn{5}{|l|}{ Customer Satisfaction (Y1) } \\
\hline Ojek online alternative transportation in congestion (Y1.1) & 0,728 & \multirow{4}{*}{0,538} & 0,500 & Valid \\
\hline Ojek online escorted safely (Y1.2) & 0,686 & & 0,500 & Valid \\
\hline I invite friends to use ride gojek (Y1.5) & 0,581 & & 0,500 & Valid \\
\hline I Suggest my brother to use ride-Gojek (Y1.6) & 0,644 & & 0,500 & Valid \\
\hline
\end{tabular}

Test Validity Customer Loyalty

\begin{tabular}{|c|c|c|c|c|}
\hline Indicator & $\begin{array}{l}\text { Loading } \\
\text { Factor }\end{array}$ & AVE & Criteria & Description \\
\hline \multicolumn{5}{|c|}{ Customer Loyalty (Y2) } \\
\hline When I use public transport, I use Ojek online (Y2.1) & 0,730 & \multirow{5}{*}{0,550} & 0,500 & Valid \\
\hline I believe an ojek online one public transportation I need (Y2.2) & 0,737 & & 0,500 & Valid \\
\hline I am proud to use transport ojek online (Y2.3) & 0,593 & & 0,500 & Valid \\
\hline Ojek online is fast safe transportation solutions (Y2.5) & 0,665 & & 0,500 & Valid \\
\hline $\begin{array}{l}\text { the driver ojek online honest in accepting the payment service } \\
\text { (Y2.6) }\end{array}$ & 0,615 & & 0,500 & Valid \\
\hline
\end{tabular}

Test Reliability

\begin{tabular}{|l|c|c|c|c|}
\hline \multicolumn{1}{|c|}{ Variable } & Cronbachs Alpha & Composite Reliability & Criteria & Description \\
\hline $\begin{array}{l}\text { Customer Satisfaction } \\
\left(\mathrm{Y}_{1}\right)\end{array}$ & 0,77 & 0,76 & 0,70 & Reliable \\
\hline Customer Loyalty $\left(\mathrm{Y}_{2}\right)$ & 0,79 & 0,80 & 0,70 & Reliable \\
\hline
\end{tabular}

Test Hypothesis

\begin{tabular}{|c|c|c|}
\hline Path & T Statistic $(>1.96)$ & Description \\
\hline Satisfaction $\rightarrow$ Loyalty & 6,795 & Significant \\
\hline
\end{tabular}


International Journal of Advances in Scientific Research and Engineering (ijasre), Vol 5 (4), April-2019 